\title{
Evaluasi Ketersediaan Obat pada Era JKN-BPJS Kesehatan di RSUD Kota Kendari Tahun 2015
}

\author{
Henny Kasmawati", Sabarudin, Siti Amaliah Jamil
}

Fakultas Farmasi Universitas Halu Oleo, Kampus Hijau Bumi Tridharma Anduonohu Jl. H. E. A. Mokodompit Kendari 93232

E-mail: hennykasmawati@uho.ac.id

\begin{abstract}
Abstrak
Ketersediaan obat merupakan komitmen pemerintah dalam melaksanakan pelayanan kesehatan. Ketersediaan obat di rumah sakit menentukan tercapainya pelayanan kesehatan yang optimal. Ketersediaan obat yang optimal adalah ketersediaan obat yang mencukupi kebutuhan bagi pasien. Penelitian ini dilakukan untuk mengevaluasi ketersediaan obat pada era JKN-BPJS Kesehatan di RSUD Kota Kendari Tahun 2015 dengan menggunakan indikator persentase nilai obat kedaluwarsa, persentase stok mati, persentase stok obat kosong (stock out), nilai TOR, dan tingkat ketersediaan obat. Penelitian ini merupakan penelitian deskriptif non eksperimental dengan pengumpulan data secara retrospektif. Data diperoleh dari pengamatan dan observasi dokumen tahun 2015 serta didukung dengan wawancara dengan Kepala Gudang Farmasi dan petugas gudang obat RSUD Kota Kendari. Hasil penelitian menunjukkan bahwa ketersediaan obat di RSUD Kota Kendari pada era JKN-BPJS tahun 2015 belum efisien dengan hasil persentase nilai obat kedaluwarsa sebesar $0,47 \%$, persentase stok mati sebesar 2,27\%, persentase stock out $15,07 \%$, nilai TOR sebesar 8,02 kali dan tingkat ketersediaan obat 18,04 bulan.
\end{abstract}

Kata kunci: ketersediaan obat, BPJS, rumah sakit, manajemen, Kendari

\section{Pendahuluan}

Ketersediaan obat sangat erat kaitannya dengan proses pengelolaan obat yang merupakan salah satu segi manajemen logistik di rumah sakit, dimana ketersediaan obat saat ini menjadi tuntutan pelayanan kesehatan [ 1 . Ketersediaan obat bagi masyarakat merupakan salah satu komitmen pemerintah dalam melaksanakan pelayanan kesehatan masyarakat. Upaya yang telah dilakukan oleh pemerintah tentunya bertujuan agar kesehatan masyarakat terjaga. Namun tidak dapat dipungkiri bahwa ketersediaan obat pada era JKN ini masih sering terjadi masalah. Melalui e-catalog hanya dapat ditemukan 200 jenis obat sementara dengan sistem DPHO (Daftar Plafon Harga Obat) bisa mencakup 600 jenis obat. Dari sisi harga obat, melalui sistem DPHO harga obat bisa ditekan hingga $50 \%$ karena volume pemesanannya besar dan mencakup seluruh Indonesia. Dengan e-catalog, jika rumah sakit kekurangan obat maka mereka harus membeli sendiri. Sementara banyak rumah sakit yang tidak mempunyai cukup dana dan pengalaman membeli obat melalui $e$ catalog. Selain itu, jarang ada pabrik obat yang mau melayani pembelian obat oleh rumah sakit dalam jumlah sedikit dan mendadak. Ini yang menyebabkan banyak rumah sakit saat ini sering kekurangan atau kehabisan obat sejak BPJS Kesehatan beroperasi. Menurut Susilowati, permasalahan obat BPJS saat ini adalah: stok obat pada produsen kosong, pengiriman terlambat, stok obat pada distributor kosong, harga obat tidak sesuai dengan $e$ catalog, beberapa obat hanya rumah sakit pemerintah yang bisa order, serta purchasing dan pengiriman lama [2].
Penelitian mengenai Evaluasi ketersedian obat di rumah sakit telah dilakukan oleh Akbar (2015) mengenai ketersediaan obat di gudang Farmasi RSUD Gunung Jati Kota Cirebon Tahun 2014 dan memperoleh hasil ketersediaan obat di gudang farmasi tahun 2014 dengan indikator tingkat ketersediaan obat di gudang farmasi memiliki persentase aman (3,58\%), berlebih (22,81\%), kurang $(73,60 \%)$, Indikator persentase obat yang sesuai FORNAS sebesar $(77,71 \%)$, indikator persentase obat kedaluwarsa $(1,14 \%)$, persentase obat rusak $(0,52 \%)$, persentase waktu kekosongan obat $(0,721 \%)$, TOR (10 kali) dan obat yang mengalami stok mati (10,31\%). Penelitian dengan topik yang sama juga dilakukanoleh Suryana (2014) mengenai evaluasi ketersediaan obat di RSUD Sleman Tahun 2013 dan memperoleh hasil ketersediaan obat dengan indikator persentase obat kedaluwarsa $(0,15 \%)$ dengan nilai $(\operatorname{Rp} 264.000)$, persentase dead stock $(6,33 \%)$, persentase stock out $(29,81 \%)$, nilai TOR (11,24 kali pertahun) dan tingkat ketersediaan obat berlebih $(61,54 \%)$, tingkat aman $(2,88 \%)$ dan tingkat kurang $(35,58 \%)$ [3].

\section{Metode}

Penelitian ini merupakan penelitian deskriptif noneksperimental dengan pengambilan data secara retrospektif di Instalasi Farmasi RSUD Kota Kendari. Data yang diambil berupa data stok obat, data obat kedaluwarsa/ rusak, data persediaan, dan penggunaan obat tahun 2015 . 


\section{Hasil dan Pembahasan}

Ketersediaan obat di rumah sakit menentukan tercapainya pelayanan kesehatan yang optimal. Ketersediaan obat yang optimal yaitu ketersediaan obat yang mencukupi kebutuhan pasien. Indikator ketersediaan obat yang digunakan terdiri dari indikator presentase nilai obat kedaluwarsa, persentase stok mati (dead stock), persentase stock out, nilai turn over ratio (TOR) dan tingkat ketersediaan obat.

\subsection{Persentase Nilai Obat Kedaluwarsa dan Rusak}

Persentase nilai obat kedaluwarsa diperoleh dari perbandingan antara nilai obat kedaluwarsa dan atau rusak dengan nilai stok opname obat dikalikan dengan $100 \%$. Obat kedaluwarsa dilihat dari stok obat yang tanggal kedaluwarsanya berakhir pada tahun 2015. Berdasarkan hasil pengamatan dokumen laporan obat kedaluwarsa Instalasi Farmasi RSUD Kota Kendari tahun 2015, diperoleh jumlah obat kedaluwarsa sebanyak 19 item obat dan tidak terdapat obat yang rusak.

Tabel 1. Persentase obat kedaluwarsa di RSUD Kota Kendari tahun 2015

\begin{tabular}{ccc}
\hline No & \multicolumn{1}{c}{ Keterangan } & Jumlah (Rp) \\
\hline 1 & Total nilai obat kedaluwarsa & 14.420 .198 \\
2 & Nilai stok opname & 3.078 .079 .971 \\
\hline Persentase obat kedaluwarsa & $\mathbf{0 , 4 7 \%}$ \\
\hline
\end{tabular}

Menurut standar yang ditetapkan, persentase obat kedaluwarsa dan rusak adalah $0 \%$, sehingga persentase nilai obat kedaluwarsa di RSUD Kota Kendari belum memenuhi standar yang telah ditetapkan. Berdasarkan keterangan kepala gudang instalasi farmasi, hal ini disebabkan karena obat yang kedaluwarsa adalah obat yang sebagian besar berasal dari pembelian tahun sebelumnya yang stok obatnya sebagian tidak berjalan, obat tidak diresepkan lagi oleh dokter dan kurangnya kasus penyakit yang menggunakan obat tersebut sehingga menyebabkan obat kedaluwarsa.

Penelitian sebelumnya di RSUD dr. R. Soedjono Selong Lombok Timur bahwa persentase obat kedaluwarsa yaitu sebesar 0,19\% dengan total kerugian sebesar Rp. 2.109.293 [4], dan di RS PKU Muhammadiyah Temanggung, persentase obat kedaluwarsa yaitu sebesar $1,79 \%$ dengan total kerugian sebesar Rp. 8.492.686 [5]. Terdapatnya obat kedaluwarsa dan rusak menunjukkan bahwa sistem perencanaan dan penyimpanan yang dilakukan belum efisien. Adanya obat kedaluwarsa atau rusak mencerminkan ketidaktepatan perencanaan atau kurang baiknya sistem distribusi terutama pada ketersediaan obat, atau perubahan pola penyakit [6]. Hal ini dapat dihindari dengan mengevaluasi setiap proses perencanaan sampai penyimpanan.

\subsection{Persentase Stok Mati}

Persentase stok mati diperoleh dari perbandingan antara jumlah item obat stok mati dengan jumlah item obat yang ada dikalikan dengan $100 \%$. Data stok mati diperoleh dari rekapitulasi kartu persediaan barang Instalasi Farmasi
RSUD Kota Kendari Tahun 2015. Berdasarkan hasil pengamatan, diperoleh jumlah obat stok mati di Instalasi Farmasi RSUD kota Kendari tahun 2015 sebanyak 19 item obat.

Tabel 2. Presentase stok mati RSUD Kota Kendari Tahun 2015

\begin{tabular}{clc}
\hline No & \multicolumn{1}{c}{ Keterangan } & Nilai \\
\hline 1 & Jumlah item obat stok mati & 19 \\
2 & Jumlah item obat yang tersedia & 698 \\
\hline & Persentase stok mati & $\mathbf{2 , 2 7 \%}$ \\
\hline
\end{tabular}

Persentase obat stok mati di RSUD Kota Kendari sebesar 2,27\%, sedangkan menurut standar stok mati sebesar $0 \%$. Hasil ini mengindikasikan nilai tersebut belum memenuhi standar yang ada. Berdasarkan keterangan kepala gudang dan petugas gudang, stok mati disebabkan karena peresepan obat yang kurang dan perubahan pola penyakit yang tidak tetap setiap tahunnya. Salah satu contohnya Primaquim $^{\circledR}$, yang merupakan salah satu obat stok mati akibat malaria tidak termasuk dalam kategori 10 besar penyakit di RSUD Kota Kendari pada tahun 2015. Selain itu, stok mati juga bisa disebabkan oleh tren penyakit yang sedang terjadi pada saat itu dan menyebabkan pemakaian terhadap obat tersebut menjadi berkurang atau dokter sudah mengganti jenis obat yang digunakan [3]. Persentase stok mati yang tinggi menunjukkan perputaran obat yang tidak lancar karena banyak persediaan obat yang tertahan dan menumpuk di gudang. Banyaknya obat yang menumpuk di gudang tentunya akan menimbulkan kerugian karena meningkatnya resiko kerusakan obat kedaluwarsa serta perputaran persediaan yang tidak lancar. Terjadinya kerusakan obat dan perputaran sediaan yang tidak lancar akan mempengaruhi pendapatan rumah sakit itu sendiri [7]. Selain itu kerugian yang disebabkan akibat stok mati adalah perputaran uang yang tidak lancar, kerusakan obat akibat terlalu lama disimpan sehingga menyebabkan obat kedaluwarsa [8]. Jika dibiarkan terus menerus terjadi, rumah sakit akan mengalami kerugian secara terus menerus.

\subsection{Persentase Stock Out}

Stock out adalah keadaan persediaan obat kosong yang dibutuhkan di instalasi farmasi. Stok kosong adalah jumlah stok akhir obat sama dengan nol. Stok obat di gudang mengalami kekosongan dalam persediaannya sehingga bila ada permintaan tidak bisa terpenuhi [9]. Persentase stock out adalah perbandingan jumlah item obat kosong dalam satu tahun dengan jumlah total item obat yang ada di rumah sakit.

Tabel 3. Presentase stock out RSUD Kota Kendari Tahun 2015

\begin{tabular}{ccc}
\hline No & \multicolumn{1}{c}{ Keterangan } & Nilai \\
\hline 1 & Jumlah item obat yang kosong & 107 \\
2 & Jumlah total itemobat & 698 \\
\hline & Persentase stock out & $\mathbf{1 5 , 3 2 \%}$ \\
\hline
\end{tabular}

Tabel 3 memperlihatkan 107 item obat yang mengalami kekosongan pada tahun 2015 di Instalasi Farmasi RSUD Kota kendari dengan persentase stock out yang terjadi sebesar $15,32 \%$, sedangkan idealnya nilai stock out adalah $0 \%$. Hal ini menunjukkan persentase stock 
out di Instalasi Farmasi RSUD Kota Kendari melebihi standar yang ditetapkan. Berdasarkan keterangan dari kepala gudang farmasi tingginya nilai stock out tersebut dikarenakan kekosongan obat pada distributor. Hal ini disebabkan karena kekosongan pada distributor obat dan keterlambatan pengiriman dari distributor obat ke gudang farmasi [10]. Kekosongan obat merupakan hal lumrah sebagai akibat dari beberapa faktor seperti obat yang dipesan belum datang, kurangnya stok nasional, dan pemesanan ditunda oleh PBF karena pembayaran/ pelunasan utang ke PBF mengalami keterlambatan. Apabila terjadi kekosongan obat/persediaan obat terkunci, maka Instalasi Farmasi RSUD Kota Kendari melakukan peminjaman obat kepada Rumah Sakit Bahteramas, Rumah Sakit Dr. R. Ismoyo, Rumah Sakit Bhayangkara dan Gudang Farmasi Kota (GFK) dengan sistem peminjaman dan dikembalikan jika obat/alkes di Instalasi Farmasi RSUD Kota Kendari sudah ada.

Stock out juga dapat terjadi karena ketidaktelitian petugas gudang dalam pemesanan obat, implementasi penggunaan formularium oleh user belum berjalan secara optimal, kekosongan pada principle (produsen), kekosongan pada distributor, terdapat permasalahan pada distributor mengenai keterlambatan penukaran faktur, keterlambatan pengiriman barang dari distributor, keterlambatan pembayaran ke rekanan, keterlambatan pemesanan akibat kelalaian petugas, kurangnya pemantauan kinerja obat [9]. Selain itu, kekosongan obat disebabkan oleh beberapa faktor antara lain tidak adanya perencanaan kebutuhan obat yang dilakukan oleh apotek. Pengadaan yang dilakukan jika obat yang dibutuhkan ataupun jika persediaan kosong. Selain itu, masih ada distributor yang menggunakan harga yang tidak sesuai (lebih tinggi) dengan $e$-catalogue sehingga apotek tidak dapat melakukan pengadaan obat karena akan menimbulkan biaya tambahan [11].

Persentase kekosongan obat menggambarkan kapasitas sistem pengadaan dan distribusi dalam menjamin kesinambungan suplai obat [6]. Dampak yang paling dirasakan akibat adanya kekosongan obat adalah terganggunya pelayanan kesehatan serta menurunnya tingkat kepercayaan pasien terhadap tenaga dan sarana kesehatan. Dalam pelayanan JKN, rumah sakit pemerintah diwajibkan menyediakan dan memberikan obat generik kepada pasien [12]. Untuk menyiasati kekosongan itu, maka rumah sakit diberi kewenangan untuk mengganti obat generik dengan obat paten yang sama dengan komponennya.

\subsection{TOR (Turn Over Ratio)}

TOR (Turn Over Ratio) digunakan untuk mengetahui berapa kali perputaran modal dalam satu tahun. Selain itu dapat untuk menghitung efisiensi pengelolaan obat. Semakin tinggi TOR, semakin efisiensi persediaan obat. TOR dapat dihitung dengan membandingkan nilai harga pokok penjualan (HPP) dengan persediaan rata-rata. Tabel 4 menunjukkan TOR pada tahun 2015 di instalasi farmasi RSUD Kota Kendari sebesar 8,02 kali telah memenuhi standar yang telah ditetapkan yaitu sebesar 8-12 kali. Rendahnya nilai TOR mengindikasikan masih banyaknya stok obat yang belum keluar sehingga mengakibatkan penumpukan obat dan berpengaruh terhadap keuntungan. Selain itu, nilai TOR yang rendah menggambarkan banyaknya stok yang belum terjual, sehingga menghambat aliran kas dan sangat berpengaruh terhadap keuntungan. Indikator ini digunakan untuk mengetahui kecepatan perputaran obat, yaitu seberapa cepat obat dibeli, didistribusi, sampai dipesan kembali.

Tabel 4. Nilai TOR (Turn Over Ratio) di RSUD Kota Kendari tahun 2015

\begin{tabular}{ccc}
\hline No & Keterangan & Jumlah $(\mathbf{R p )}$ \\
\hline 1 & HPP (Harga Pokok Penjualan) & 5.722 .676 .600 \\
2 & Rata-rata nilai persediaan obat & 713.459 .574 \\
\hline & TOR & $\mathbf{8 , 0 2}$ kali \\
\hline
\end{tabular}

\subsection{Tingkat Ketersediaan Obat}

Tingkat ketersediaan obat adalah tingkat persediaan obat baik jenis maupun jumlah obat, yang diperlukan oleh pelayanan pengobatan dalam periode waktu tertentu, diukur dengan cara menghitung persediaan obat dan pemakaian rata-rata perbulan. Indikator tingkat ketersediaan obat di instalasi farmasi digunakan untuk mengetahui kisaran kecukupan obat. Kecukupan obat merupakan indikasi kesinambungan pelayanan obat untuk mendukung pelayanan kesehatan di rumah sakit.

Tabel 5. Ketersediaan Obat di di RSUD Kota Kendari tahun 2015

\begin{tabular}{clc}
\hline No & \multicolumn{1}{c}{ Keterangan } & Jumlah (Rp) \\
\hline 1 & Jumlah stok obat & $1.985 .270,00$ \\
2 & Rata-rata pemakaian obat /bulan & $110.025,83$ \\
\hline & Tingkat ketersediaan obat & $\mathbf{1 8 , 0 4}$ bulan \\
\hline
\end{tabular}

Data dari Tabel 5 menunjukkan ketersediaan obat di Instalasi Farmasi RSUD Kota kendari sebesar 18,04 bulan, seduai dengan standar umum tingkat ketersediaan obat (12-18 bulan). Hal ini menunjukkan bahwa ratarata tingkat ketersediaan obat di RSUD Kota Kendari telah mencukupi kebutuhan rumah sakit. Ketersediaan obat sebagai unsur utama dalam pelayanan kesehatan selain keterjangkauan, keamanan, mutu dan manfaat, faktor ketersediaan obat sangat terkait dengan pendanaan. Salah satu persyaratan penting dari pelayanan kesehatan masyarakat yang bermutu adalah tersedianya obat yang cukup, baik jenis maupun jumlahnya setiap saat diperlukan oleh masyarakat dan mutu yang terjamin. Obat dengan tingkat kecukupan kurang akan berdampak pada pelayanan pasien karena kebutuhan obat pasien tidak terpenuhi atau terlayani dengan baik sehingga pengobatan rasional obat tidak akan tercapai. Solusinya adalah mengevaluasi dan melakukan sistem perencanaan dan pengadaan obat dengan selektif disesuaikan dengan kebutuhan RS serta mengacu pada prinsip efektif, aman, ekonomis dan rasional [13].

\section{Kesimpulan}

Ketersediaan obat di RSUD Kota Kendari pada era JKN-BPJS tahun 2015 belum efisien, dengan hasil persentase obat kedaluwarsa sebesar $0,47 \%$, persentase stok mati $2,72 \%$, persentase stock out $15,32 \%$, nilai TOR 8,02 kali, dan tingkat ketersediaan obat 18,04 bulan. 


\section{Daftar Pustaka}

1. Quick JD, Hume ML, Rankin JR, O'Connor RW. Managing Drug Supply, $3^{\text {rd }}$ Edition, Revised and Expanded, West Hartfort: Kumarian Press , 2012

2. Susilowati V. Peningkatan Pelayanan Obat Bagi JKNBPJS Kesehatan. Semarang: Badan Penyelenggara Jaminan Sosial Kesehatan, 2015.

3. Akbar Z. Evaluasi Tingkat Ketersediaan Obat Di Gudang Farmasi Rumah Sakit Umum Daerah Gunung Jati Kota Cirebon Tahun 2014. Skripsi. Yogyakarta: Universitas Islam Indonesia. 2015

4. Qiyaam N. Evaluasi Manajemen Penyimpanan Obat Di Gudang Obat Instalasi Farmasi Rumah Sakit Umum Daerah Dr. R. Soedjono Selong Lombok Timur. Jurnal Ilmiah Ibnu Sina, 2016, 1(1);61-70.

5. Fakhriadi A, Marchaban, Pudjaningsih D. Analisis Pengelolaan Obat di Instalasi Farmasi Rumah Sakit PKU Muhammadiyah Temanggung Tahun 2006, 2007 dan 2008, Jurnal Manajemen dan Pelayanan Farmasi, 2011, 1(2);94102

6. Departemen Kesehatan Republik Indonesia. Pelatihan Pengelolaan Obat Di Kabupaten/Kota. Jakarta: Direktorat Jenderal Pelayanan Kefarmasian dan alat Kesehatan, Direktorat Bina Obat Publik dan Perbekalan Kesehatan,
Departemen RI bekerjasama dengan JICA, 2007

7. Nugroho I. Evaluasi Penyimpanan dan Penggunaan Obat di rumah Sakit Umum Kota Yogyakarta Tahun 2006 Dan 2007, Skripsi, Yogyakarta: Universitas Gadjah Mada. 2008.

8. Pudjaningsih D. Pengembangan Indikator Efisiensi Pengelolaan Obat di Instalasi Farmasi Rumah Sakit. Tesis. Yogyakarta: Universitas Gadjah Mada. 1996

9. Pratiwi A, Stock Out Obat di Gudang Logistik Perbekalan Kesehatan Rumah Sakit Islam Jakarta Cempaka Putih pada Triwulan I Tahun 2009. Skripsi. Jakarta: Universitas Indonesia. 2009.

10. Suryana. Evaluasi Ketersediaan Obat di Rumah Sakit Umum Daerah Sleman Tahun 2013. Skripsi. Yogyakarta: Universitas Islam Indonesia. 2014.

11. Ianathasya, Mardiati N. Gambaran Stock Out Obat Program Rujukan Balik Bagi Peserta JKN Di BPJS Kesehatan Jakarta Pusat Pada Juni-Agustus 2014, Jakarta: Universitas Indonesia. 2015.

12. Sekretaris Negara Republik Indonesia. Undang-Undang Republik Indonesia Nomor 40 Tahun 2004 Tentang Sistem Jaminan Sosial Nasional, Jakarta: Departemen Kesehatan Republik Indonesia. 2004

13. Pudjaningsih D, Budiono S. Pengembangan Indikator Efisisensi Pengelolaan Obat di Instalasi Farmasi Rumah Sakit, Logika, 2006, 3(1). 